\title{
Assessment of Beef Cattle Production and Marketing Practice in Eastern Oromia, Ethiopia
}

\author{
Birmaduma Gadisa Muleta*1 Yesihak Yusuf Mummed ${ }^{2} \quad$ Mohammad Yousuf Kurtu $^{2}$ \\ 1.Mechara Agricultural Research Center P. O. Box 19, Mechara, West Hararghe Ethiopia \\ 2.Haramaya University P.O. Box 138, Dire Dawa, Ethiopia
}

\begin{abstract}
A cross sectional study was conducted with the objectives to assessing beef cattle production and trading system in eastern Oromia. Structured questionnaire and a onetime observation were conducted on 50 producers and 40 traders a total of 90 beef cattle producers and traders, which were, include purposively in the study using random sampling techniques to generate set data. Based on the result of survey made the producers kept cattle for multiple purposes, on average age of 6-9 years. Most farmers sold animals in near by village market. Major constraints for producers were feed shortage, animal health and lack of improve breeds. Traders transported mixed cattle in irrespective of ages, breeds, and sex to their destination which was on average $118.5 \pm 19 \mathrm{~km}$ via vehicle. Harar breed had high demand in local market while Boran was used for export purpose. The perception of traders on factors affecting the quality of beef indicated that beating, feed shortage, and agroecology were important being ranked $1^{\text {st }}, 2^{\text {nd }}$ and $3^{\text {rd }}$ respectively. From this study, it was concluded that quality of beef produced in study areas was relatively older. Resulted tough beef source. It is recommended that strategy should be developed to encourage premium payment for young cattle marketing that is not exposed to draft service and develop strategy to breed improvement to overcome stock decreases.
\end{abstract}

Keywords: Beef, Cattle age, Feed resource, Perceptions

DOI: $10.7176 / \mathrm{FSQM} / 85-04$

Publication date:March $31^{\text {st }} 2019$

\section{INTRODUCTION}

Ethiopia owns immense untapped livestock resources scattered over diverse agroecology. Environmental conditions of the country made conducive to the diversity of livestock production. The total cattle population of the country estimated about 57.83 million, 28. 89 million sheep, 29.70 million goat, 60.51 million poultry, 2.08 million horses, 7.88 million donkeys, 1.23 million camels and 0.41 million mules (CSA, 2016/17). Even though the country is blessed with huge livestock resources, the share of meat and other slaughter by-products were underutilized compared to its potential (Eyob and Zewudu, 2016).

Cattle are kept mainly for draft power, milk and manure production and are usually only sold when they are too old for these purposes, or drought or cash shortages force people to sell (Matawork, 2017). This happened in Ethiopia due to knowledge gap, limited promotion done in marketing; limited intra-Africa trade integration; poor linkage among stakeholders; few market outlets and other interlinked problems (EMDIDI, 2016). Commonly there are three different type of beef cattle production system in Ethiopia. Those are traditional methods, Hararghe fattening and by product based production system. Each of the production systems had their own characteristics and had positive and negative impacts.

The main beef cattle channel actor were producers, traders, cooperatives, abattoirs, butchers, processors, and consumers (Kefyalew, 2011). However, in Ethiopia there is less business communication and linkage between livestock chain actors (Tekeba, 2016). The actors mostly act individually as their benefit. Live animals are marketed through traditional marketing routes developed over years, which were based on visual assumption on body conformation animal. This happened due to the terminal market have not accessibility of weight which result lengthened value chain of animal marketing. In other wise in Ethiopia, recent studies estimated that annual illegal flow of livestock through boundaries reaches high than formal one.The actual performance has remained very low, leaving most of the projected livestock off take for the unofficial cross-border export and the domestic market (Fekadu et al, 2017).

Marketing chains need institutional arrangements, public investment and enabling policies and regulations (EMDIDI, 2016). Marketing dairy calf as beef cattle was rare which otherwise contribute to cattle supply in beef market (Mummed and Webb, 2014). Understanding producers and other stakeholder behavior on dairy beef is vitally important. Cross sectional study was conducted from October, 2017 to January, 2017. After interviewing traders at two big livestock terminal market namely Adama and Dire Dawa and information was indentified about the original source of cattle to terminal market. Then fattening farms and one time visit of other extensive producers was made and the required information was collected by structured questioner and direct observation. The study was conducted with the objective to assess beef cattle production and trading practice, production and marketing constraint, breed and age preference for marketing and perception for beef quality determinants in Eastern Oromia. 


\section{MATERIALS AND METHODS}

\section{Description of the Study Area}

Adama town towns is situated at $92 \mathrm{~km}$ East of Adiis Ababa on the highway from Addis Ababa to Harar. The towns have good infrastructures that facilitates and link marketing in the national and international. The annual average minimum and maximum temperature of Adama town is 18 and 32 , respectively. The specific geographical location of the Adama town is on the geographic coordinates of: $8^{\circ} 33^{\prime} 00^{\prime \prime} \mathrm{N}$ and $39^{\circ} 16^{\prime} 00^{\prime \prime E}$. The altitude of the city is $1627 \mathrm{~m}$ above sea level (Arse et al., 2013).

Dire Dawa town is located $520 \mathrm{~km}$ to Eastern Addis Ababa Capital city of Ethiopia on the halfway point between the Djibouti - Addis Ababa railway line. The average temperature $22.5 \mathrm{C}^{\circ}$, the altitude of the towns is $1200 \mathrm{~m}$ above sea level and average annual rain fall was $626 \mathrm{~mm}$. The specific geographical location is $9^{\circ} 35^{\prime} 35^{\prime \prime} \mathrm{N}$ and $41^{\circ} 51^{\prime} 58^{\prime \prime} \mathrm{E}$. The town is being one of the busiest business cities of the country among the valuable area of the Eastern Oromia zone. The town is serves as a good holiday destination for visitors from Djibouti and the Middle East. Having an international airport serves as an important gate way to the Hararge areas marking an important tourist destination center in the country.

Qullubi town is located in Meta district, Eastern Hararghe zone, Oromia National Regional state, Ethiopia. The specific geographical location of the Qullubi is on the geographic coordinates of; 9 $35^{\prime} 35^{\prime \prime} \mathrm{N}$ and 41 51 '58'E. From the district of Eastern Hararghe, cattle from Qullubi town areas are well famous at Dire Dawa and Harar terminal market. The town is located $464 \mathrm{~km}$ form Addis Ababa capital cities of Ethiopian and $62 \mathrm{~km}$ from Harar town. The town is a popular pilgrimage site of the Ethiopia Coptic Orthodox Church, eventful religious festivals are held twice a year at this town on July 26 and December 28, which tens and thousands of pilgrims from all over the country attend.

Bale Robe is located in the Bale Zone of the South-Eastern Oromia National Regional state, Ethiopia. This town has is situated at latitude and longitude of $7^{\circ} 7^{\prime} \mathrm{N} ; 40^{\circ} 0^{\prime} \mathrm{E}$ with an elevation of 2,492 meters $(8,176 \mathrm{ft})$ above sea level. It is located about 430 kilometers from Ethiopia's capital Addis Ababa. Bale Robe has Airport facilities with neighboring Goba towns. The town is proximity for notable tourist attractions include the Sof Omar Caves, Bale Plateaus and Dinsho park were different indigenous animal and plants species situated.

Sagure town is the administrative center Dagalu and Tejo district, Arsi zone, Oromia National Regional state, Ethiopia. The altitude of this district ranges from 2500 to 3560 meters above sea level. This town has a latitude and longitude of $07^{\circ} 45^{\prime} \mathrm{N} ; 39^{\circ} 09^{\prime} \mathrm{E}$ with elevation of 2568 meters above sea level. It is located about $10 \mathrm{~km}$ from zonal town of Asella and $185 \mathrm{~km}$ by road from Ethiopia's capital Addis Ababa.

Sampling procedures and survey data collection methods

The survey data were collected between the mid of September to the beginning of December 2017. Both qualitative and quantitative data were collected to evaluate production and marketing system of beef cattle in Eastern part of Oromia. Totally 90 individual respondent were interviewed using structured questionnaires. The questionnaires were prepared to generate data on perception of cattle producers (50) and traders (40) at different location. Purposive sampling techniques were used to select the respondents. The questionnaires were prepared differently for producers and traders. The traders were asked at Adama and Dire Dawa terminal market during they sold their animal for butchers, consumers and large traders/ exporters. After information was collected about, potential cattle source to respective terminal market from traders the cattle producers were also interviewed at in-situ of their production areas. The producers were interviewed from intensive dairy farm and feed lot in Adama and Dire Dawa towns, additional data were collected from Qullubi (Meta district) area, Bale Robe (Sinana district), Sagure (Digalu and Tijo district). Adama and Dire Dawa towns are big cattle terminal market in Eastern Oromia, Ethiopia.

\section{Methods of survey data analysis}

Descriptive statistics, Garret ranking techniques, Likert rating scale, and Chi-square were used to analyze collected quantitative data through using the Statistical Package for Social Science software (SPSS) version 20. The qualitative data was analyzed through description, explanation, and narration.

Descriptive statistics, such as percentage, mean and standard deviation were used to explain the different sociodemographic characteristics and other data collected by interview from respondents. Garret's ranking technique was employed to rank major constraints of beef cattle production, seasonal feed availability, beef quality determinants, preference for the breeds and ages. The percent position of each rank were calculated using the formula of Garrett (1969).

Percent position $=100($ Rij- 0.5$) / \mathrm{Nj}$ Where;

$R_{i j}=$ Rank given for the $i^{\text {th }}$ items by the $j^{\text {th }}$ individual.

$\mathrm{N}_{\mathrm{j}}=$ Number of items ranked by the $\mathrm{j}^{\text {th }}$ individual.

By using the score card by Garret scores were allocated to the percentage values. Then for each factor, the scores of individual respondents were added together and divided by the total number of respondents for whom scores have been added. The mean scores for all the factors were ranked by arranging in descending order. Five 
Likert (1932) rating scale was employed to analyze the perception of stakeholder on beef quality determinant. The Likert scale of 1 to 5 points was used to measure respondents' perception on beef quality determinants for positive items, strongly disagreed awarded 1 point, disagreed 2 points, neutral 3 points, agreed 4 points and strongly agreed 5 points. On the other hand, the reverse values were assigned for negative items. To create a Likert scale perception index five Likert items employed to develop a composite perception index and the items filled each respondent. Then the mean scores for all the factors ranked by arranging in descending order. The Likert scale of 1 to 5 points with a mean score of three (3) was used as a cut-off point to measure respondents' perception.

The mean score of three and above was used to denote agree while a mean score below three was used to denote disagree for positive items while the reverse decision was given on the contrary for the negative items. Chi-square test was used for one categorical dependent and two or more levels category of independent variables. It was employed to see if there were significant mean and proportion differences between categories in terms of different explanatory variables.

\section{RESULTS AND DISCUSSION \\ Cattle producers}

DEMOGRAPHIC CHARACTERISTICS OF CATTLE PRODUCERS AND TRADERS

Demographic characteristics of producers and traders in study areas are presented in Table 1. About 50 cattle produces were questioned. Out of the total respondents, about $82 \%$ were male while $18 \%$ were female. The current finding is similar with Yadenakachew (2016) who reported male respondents were dominance on market-oriented beef cattle fattening in South Omo of Ethiopia. With regards to educational level, most of $97.5 \%$ of the interviewed producers were literate from 1 grade to degree/diploma, with predominantly primary school $(55 \%)$ and only about $(2.5 \%)$ were illiterate. Most of respondent were in active productive age groups with an average of $41.86 \pm 13.76$ years. This was good opportunity to transfer relevant technology to producers for exploit livestock resources in the study area. Similar to producers majority of interviewed, traders were male $97.5 \%$ and most of them were in productive age group minimum 21 years and maximum 68 years in average $36.68 \pm 10.24$ years. They, have good working experience as cattle traders, which were on average about 10 years. The most of the respondents assume that, they are engaged in a profitable business and gave them good opportunity to know their surrounding as they travel for their business. Among the respondent traders, only $2.5 \%$ were illiterates the others $97.5 \%$ were literate.

Table 1. Demographic characteristics of producers and traders

\begin{tabular}{|c|c|c|c|c|c|}
\hline \multirow{2}{*}{ Variable } & \multirow{2}{*}{ Attribute } & \multicolumn{2}{|c|}{ Producers $(n=50)$} & \multicolumn{2}{|c|}{ Traders $(n=40)$} \\
\hline & & $\mathrm{n}$ & $\%$ & $\mathrm{n}$ & $\%$ \\
\hline \multirow[t]{2}{*}{ Sex } & Male & 41 & 82 & 39 & 97.5 \\
\hline & Female & 9 & 18 & 1 & 2.5 \\
\hline \multirow[t]{5}{*}{ Educational status } & Illiterates & 12 & 24 & 1 & 2.5 \\
\hline & Primary school & 28 & 56 & 22 & 55 \\
\hline & High School & 8 & 16 & 13 & 32.5 \\
\hline & Dip/degree & 2 & 4 & 4 & 10 \\
\hline & Min & Max & Mean \pm SD & Max & Mean $\pm \mathrm{D}$ \\
\hline Age (yr) & 20 & 78 & $41.86 \pm 13.73$ & 21 & $36.68 \pm 10.24$ \\
\hline TE(yr) & - & - & - & 53 & $9.42+9.69$ \\
\hline
\end{tabular}

$\mathrm{n}=$ Number of respondents, Dip= Diploma, $\mathrm{Yr}=$ Year, $\mathrm{SD}=$ Standard deviation, $\mathrm{TE}(\mathrm{yr})=$ trading experience

\section{Purposes of cattle production}

The purpose of keeping cattle in the study areas are presented in Table 2. The result of the survey indicated that the cattle were kept for multipurpose $(54 \%)$ in the study area like; milk production, draft power, income generation and prestige. Moreover, it was observed that subsistent production system with single purpose like for milk production, or meat, or draft purpose were noted in study areas. Majority of the respondents keep cattle for draft power in Sagure, Bale Robe, and Kulubi area. Producers sold oxen when they got old after exempted from draught purpose. Similarly, cows were sold after culled from milk purpose the result was agreement with Yesihak and Edward (2015). Location wise producers from Adama and Dire Dawa used cattle for specific purpose of either milk or beef. The reason of keeping cattle for specific purpose might be due to practice of market-oriented production system. In addition to that cattle were kept for agricultural purpose, manure, as banking and saving insurance. Similarly, keeping cattle for the agricultural purpose, manure, as banking and saving insurance in the rural area of the high land were reported by Mummed and Webb (2015); EMDIDI (2016); Eyob and Zewudu (2016). 
Table 2. The purpose of keeping cattle in the study areas

\begin{tabular}{|c|c|c|c|c|c|c|c|}
\hline \multirow[b]{2}{*}{ Purpose } & \multicolumn{3}{|c|}{ Location } & \multirow[b]{2}{*}{$\begin{array}{l}\text { Dire Dawa } \\
(7)\end{array}$} & \multirow[b]{2}{*}{ Kulubi (13) } & \multirow{2}{*}{$\begin{array}{l}\text { Total } \\
\mathrm{n}(50)\end{array}$} & \multirow[b]{2}{*}{$\chi^{2}$} \\
\hline & Adama (10) & $\begin{array}{l}\text { Sagure } \\
(10)\end{array}$ & Robe (10) & & & & \\
\hline Multiple & $3(30)$ & $5(50)$ & $8(80)$ & (0) & $11(84.6)$ & $27(54)$ & \\
\hline Milk & $3(30)$ & $1(10)$ & $0(0)$ & $3(42.8)$ & $1(7.7)$ & $8(16)$ & 48.66 \\
\hline Draft & $0(0)$ & $2(20)$ & $2(20)$ & $0(0)$ & $1(7.7)$ & $5(10)$ & $* * *$ \\
\hline Meat & $3(30)$ & $0(0)$ & $0(0)$ & $2(28.6)$ & $0(0)$ & $5(10)$ & \\
\hline Milk \&meat & $0(0)$ & $1(10)$ & $0(0)$ & $2(28.6)$ & $0(0)$ & $3(6)$ & \\
\hline Income & $1(10)$ & $1(10)$ & $0(0)$ & $0(0)$ & $0(0)$ & $2(4)$ & \\
\hline
\end{tabular}

Multiple $=$ milk, meat, draft and income, $\mathrm{n}=$ number of the respondents, $\chi^{2}=$ Chi-square, $(\mathrm{x})=$ number in bracket is percent.

\section{Management of cattle by producers}

Management of cattle in study areas are presented in Table 3. The result of the study showed that about $64 \%$ respondents provided multiple management (locally available feed resource by allocate grazing land/concentrate, river water/clean water, shade and take care of health) of their cattle. The common feed resource used for the animals in the study area was grazing pasture, pruning fodder tree, crop residues. Similar result were reported by Estefanos et al (2014) at West and East Hararghe zone of Oromia National Regional state of Ethiopia. However, feed resource availability were depends on season of crop production and availability natural pastureland.

Housing was practiced for calves to weaning age with subsistent farmers in the study areas. With intensive farming system in the study, areas housing were available for all age groups of cattle. In the study areas female cattle were kept for a longer periods according of the producers $(60 \%)$ usually to the average of 6 to 9 years. Majority of respondent (56.5\%) kept male cattle from one to two years. Within this one to two years, bulls were used for ploughing, then after replaced by other young stock, the former being marketed for beef purpose. However, if these male cattle were born on the farm, some producers kept them for a longer period as they used them for drought purpose after being mature enough. This scenario was a bit different in the intensive farms, where the majority $(6.5 \%)$ of the producers responded that they keep male cattle only for about 6 months and culled them from the farm.

Table 3. Management of cattle in study areas

\begin{tabular}{|c|c|c|}
\hline Variable $(n=50)$ & \multirow{2}{*}{$\mathrm{n}$} & \multirow{2}{*}{$\%$} \\
\hline Management provide for cattle & & \\
\hline Allocate grazing land and used crop residues for cattle & 2 & 4 \\
\hline Provided feed and clean water, health care (conv.) and house (shade) & 5 & 10 \\
\hline Fetches river water, health (traditional and conv.) and allocate grazing land & 11 & 22 \\
\hline Provided multiple management $* *$ & 32 & 64 \\
\hline \multicolumn{3}{|l|}{ Length of time female cattle $(\mathrm{n}=40)$ kept on farm } \\
\hline$<1$ years & 6 & 15 \\
\hline $2-6$ years & 8 & 20 \\
\hline $6-9$ years & 24 & 60 \\
\hline$>9$ Year & 2 & 5 \\
\hline \multicolumn{3}{|l|}{ Length of time male cattle $(n=46)$ kept on farm } \\
\hline$<6$ month & 3 & 6.52 \\
\hline Up to 2 year * & 26 & 56.52 \\
\hline $2-6$ year & 5 & 10.87 \\
\hline $6-9$ year & 10 & 21.74 \\
\hline$>9$ year & 2 & 4.38 \\
\hline
\end{tabular}

$\mathrm{n}=$ Number of respondents, $*=$ shows male cattle from market, Conv. Conventional, Multiple management ${ }^{* *}=$ Health care, feed, water provide

\section{Feed availability}

Feed availability in study areas are presented in Table 4. The result revealed that natural pasture, crop residues, household left over and industrial by-products were the major feed available throughout a year in the study area. The importance of feed resource ranking indicated that natural pasture, crop residues, household left over and industrial by-products were $1^{\text {st }}, 2^{\text {nd }}, 3^{\text {rd }}$ and $4^{\text {th }}$ during the wet season. In the dry season crop residues was ranked first and the most important followed by industrial by-product, house left over and natural pasture, respectively. Despite feed resources availability varied across seasons, natural pasture and crop residues were the most important feed source throughout the year in the study area. The current finding was in line with Adugna (2008) 
and Diriba (2014) who reported native pastures and crop residues as main feed resource in mixed farming system. Depending on agro-ecology and crop production system, the different locations of studied had different types of crop residues. In Kulubi area, sorghum and maize crop residues was the most important animal feed resource. This finding was in line with Estefanos et al. (2014) who reported that crop residues (Sorghum and Maize) and natural pasture were the major feed resource for cattle in the West and East Hararghe high land.

Table 4. Feed availability in study areas

\begin{tabular}{|c|c|c|c|c|c|c|c|c|c|}
\hline \multicolumn{2}{|c|}{ Season } & \multirow[t]{2}{*}{ Variable } & \multicolumn{4}{|c|}{ Ranked value } & \multirow[b]{2}{*}{$\mathrm{n}$} & \multirow{2}{*}{$\begin{array}{l}\text { Mean } \\
\text { Score }\end{array}$} & \multirow{2}{*}{ Rank } \\
\hline & & & $1^{\text {st }}$ & $2^{\text {nd }}$ & $3^{\text {rd }}$ & $4^{\text {th }}$ & & & \\
\hline \multirow{3}{*}{$\begin{array}{l}\text { Wet } \\
\text { feed }\end{array}$} & season & Natural pasture & 40 & 1 & 5 & 3 & 49 & 66.88 & 1 \\
\hline & & Crop residues & 3 & 19 & 17 & 11 & 50 & 46.56 & 2 \\
\hline & & Household left over & 0 & 6 & 17 & 29 & 49 & 38.10 & 3 \\
\hline \multirow{5}{*}{$\begin{array}{l}\text { Dry } \\
\text { feed }\end{array}$} & & Industrial by product & 7 & 6 & 10 & 7 & 50 & 29.52 & 4 \\
\hline & season & Crop residues & 40 & 10 & 0 & 0 & 50 & 69.6 & 1 \\
\hline & & Industrial by product & 9 & 34 & 6 & 1 & 50 & 57.04 & 2 \\
\hline & & Household left over & 1 & 4 & 26 & 18 & 50 & 38.54 & 3 \\
\hline & & Natural pasture & 0 & 2 & 16 & 30 & 48 & 33.88 & 4 \\
\hline
\end{tabular}

$\mathrm{n}=$ Number of respondents

In Arsi and Bale zone, barley and wheat crop residues were the main feed used during the dry season. The result of the current study were in line with Solomon (2008), who reported that cereal crops residues usually from barley and wheat were the most important feed resources in dry season in Bale and Arsi zone.

Intensive farming system owners responded that they were almost entirely dependent on outside feed resources like industrial by-products (noug seed cake, cotton seed cake, bean bran and wheat bran), maize (grain and bran) and different crop residues (Teff, barley, maize, and sorghum). The result was supported by Genet et al. (2017), where they came to similar conclusion for commercial beef cattle fattening practiced in East Shoa Zone

\section{Beef cattle marketing system}

Cattle marketing system in the study areas are presented in Table 5. The result revealed that the majority of respondents $(68 \%)$ responded that they rear cattle only for subsistence instead of profit making. Those respondents who kept the cattle for market-orientation were from Adama and Dire Dawa cities practicing intensive production system. Despite, intensive farm produced cattle for the market purpose; getting low price for cattle, unnecessary involvement of brokers in the local and export market, higher cost of feed, less preference for dairy beef were the major bottleneck to producers. Absence of weight based price determination on the market and rapid increasing cost of feeds were also reported contributed to the problems.

Majority of producers $(64 \%)$ sold their animals when age exceeded 5 years. The rests sold animal without considering the age to satisfy immediate cash need and cover children school fee. The majority of respondents did not often fatten their animals before selling. However, some of the producers practiced fattening, for the export market. This finding was comparable with Arse (2013); most producers do not often fatten and received market information before selling their cattle.

The producers sold cattle at local market, which have an average distance of 1-10 km ranges traveling 15 minutes to 2:30 hrs away from their village. Farmers had insufficient information's on price of cattle at secondary and terminal markets. The few numbers of producer sold well fatten cattle to secondary, terminal and agents to exporter markets, based on information from personal visiting of markets, friends and mass media. Increasing access to market information is important as it enhances efficiency of marketing system for farmers.

About $46 \%$ of farmers sold cattle twice a year. This might be associated with biannual demanded for money, which might be need to purchasing of agricultural input before plantation of crops and to cover school expanse for children at start of year. This finding was similar to the report of Arse (2012) who reported producers sold their animals twice a year. The cattle-selling price in the past 5 to 10 years had increasing trend, which might be associated with inflation, increase in cost of inputs and other related expenses for cattle production. The farmers in the study areas sold cattle to satisfy immediate cash need, purchases of agricultural inputs and replace old cattle the body conditions of the cattle were not criteria for sale. These result in harmony with the concept that the majority of the cattle producers practiced a subsistent production system rather than market-oriented. Belete et al. (2010) reported comparable findings from the traditional cattle production system where emaciated oxen were sold after the ploughing season while they were in poor body conditions. 
Table 5. Cattle marketing system

\begin{tabular}{llcc}
\hline Variable & Attribute & $\mathrm{N}$ & $\%$ \\
\hline Produce cattle for marketing & Yes & 16 & 32 \\
& No & 34 & 68 \\
\hline Practice fattening before selling & Yes & 11 & 22 \\
& No & 39 & 78 \\
\hline Collect market information & Yes & 3 & 6 \\
& No & Mass- media & 94 \\
\hline \multirow{3}{*}{ Source of information } & personal visiting to market & 2 & 4 \\
& Friends & 39 & 78 \\
\hline Selling frequency ( per year) & 1 & 9 & 18 \\
& 2 & 15 & 30 \\
& 3 & 23 & 46 \\
& 4 & 11 & 22 \\
\hline Trends of cattle price & Increase & 1 & 2 \\
\hline Reason for selling cattle & Decrease & 49 & 98 \\
& Immediate cash needed & 1 & 2 \\
\hline
\end{tabular}

\section{Constraints of beef cattle production}

Constraints of beef cattle production in the study areas are presented in Table 6. Accordingly, Garret ranking technique ranked the constraints based on severity order. Feed shortage was a major constraint of cattle production ranked first followed by lack of an adequate veterinary service, improved breed, production technologies and fattening facilities (land and house), respectively. This might be due to decreases grazing land, lack of improved feed and frequently increased the cost of industrial by-product. Belay et al. (2012) and Genet et al. (2017) reported a similar result with the current finding on cattle production constraint. The concerned body should be established improved forage in different zones, creating awareness on feed resource available management and establishing a feed industry sub-marketing center in close to where most beef cattle sources to enhance the sustainable supply of beef cattle by alleviating the feed scarcity and enhance its quality to fully exploit the production.

Table 6. Constraints of beef cattle production

\begin{tabular}{|c|c|c|c|c|c|c|c|c|c|c|}
\hline \multirow{2}{*}{ Variable } & \multicolumn{8}{|c|}{ Rank value $(\mathrm{n}=50)$} & \multirow[b]{2}{*}{ MS } & \multirow[b]{2}{*}{ Rank } \\
\hline & $1^{\text {st }}$ & $2^{\text {nd }}$ & $3^{\text {rd }}$ & $4^{\text {th }}$ & $5^{\text {th }}$ & $6^{\text {th }}$ & $7^{\text {th }}$ & $8^{\text {th }}$ & & \\
\hline Shortage of feed resource & 36 & 8 & 4 & 2 & 0 & 0 & 0 & 0 & 75.4 & 1 \\
\hline Inadequate health service & 2 & 4 & 1 & 8 & 8 & 2 & 4 & 1 & 57.08 & 2 \\
\hline Lack of improved breeds & 2 & 2 & 6 & 10 & 6 & 4 & 9 & 1 & 54.28 & 3 \\
\hline Inadequate technologies & 5 & 7 & 7 & 10 & 9 & 3 & 6 & 3 & 54.04 & 4 \\
\hline Lack of fattening place & 1 & 6 & 6 & 5 & 8 & 8 & 5 & 1 & 48.1 & 5 \\
\hline Lack of credit service & 2 & 4 & 6 & 6 & 7 & 7 & 7 & 1 & 47.04 & 6 \\
\hline Lack of market information & 0 & 0 & 6 & 4 & 5 & 5 & 8 & 2 & 46.36 & 7 \\
\hline Shortage of water supply & 2 & 0 & 3 & 6 & 7 & 8 & 4 & 10 & 43.42 & 8 \\
\hline
\end{tabular}

$\mathrm{n}=$ Number of respondents, $\mathrm{MS}=$ mean score

\section{Cattle traders}

\section{Sources of beef cattle and marketing system}

Beef cattle source for Adama and Dire Dawa terminal marketing are presented in Table 7. The current survey result revealed that the source cattle supplied for Adama terminal market were from Adama intensive farm, and subsistent farmers from Arsi, Bale, West Hararghe and East Shoa zones. For Dire Dawa terminal market, the cattle were supplied from subsistent farmers East and West Hararghe zones and intensive farms of in the city.

The beef cattle trading were year-round activities for majority of the traders $(67.5 \%)$. Few proportions of the traders $(32.5 \%)$ were engaged in beef cattle trading on a seasonal basis. This engagement were during holidays, after crop harvest and based on demands by butchers/institutions most of the year. The male cattle aged between 6 to 9 years marketed on terminal market, which was followed by age group 4 to 6 years. However, beef cattle greater than 9 years rarely marketed. According to the respondents, cattle less than four years were demanded for breeding and draft purpose. The price of cattle was determined through bargain between traders 
and buyers. Bargain was based on body conformation and visual observation of the size as weighing scale was not available at cattle market. Harko (2015); Yednekachew et al.(2016) reports similar finding on livestock marketing system in Ethiopia is not developed in well, its characterized by markets that lack basic infrastructure, facilities like cattle pen, weighing scale, water troughs, feed and market information.

Table 7. Beef cattle source for Adama and Dire Dawa terminal marketing

\begin{tabular}{llc}
\hline Variable & \multicolumn{1}{c}{ Attribute } & $\%$ \\
\hline Source beef Cattle to Adama & Arsi (Deksis, Sagure, Asala) & 55 \\
& Bale (Robe, Goro, Goba) & 20 \\
& West Hararghe (Hirna, Badesa, Chiro and Galamso) & 15 \\
& Intensive farm (Dairy and feed lot) & 5 \\
& Other & 5 \\
\hline Source of beef cattle for Dire & East Hararghe (Chalanko, Badeno, Watter and Fadis) & 65 \\
Dawa & West Hararghe ( Badesa, Hirna, Galamso) & 25 \\
& Intensive farm and kebele's belong to Dire Dawa & 5 \\
& Other & 5 \\
\hline Time of beef cattle trade & Year round & 67.5 \\
& Seasonal based & 32.5 \\
\hline Sex of beef cattle preferred for & Only male & 67.5 \\
traders & Only female & 2.5 \\
& Both sexes & 30 \\
\hline Age category in market & 4- 6 year & 40 \\
& 6- 9 year & 55 \\
\hline & $>9$ year & 5 \\
\hline
\end{tabular}

$\mathrm{n}=$ Number of respondents

\section{Beef cattle transport}

Transport of cattle to terminal markets are presented in Table 8. The survey result revealed that majority of traders $(77.5 \%)$ transported beef cattle from primary market to terminal market by vehicle. For nearby markets, they used tracking methods of transport. This indicated that vehicle was common means of trasport for longdistance cattle transport in the study areas. Similar result was reported by Josifine (2013), in which about (79\%) of respondents were transported cattle from Ambo to Kera market by vehicle. The average traders transported cattle to destinations market were $118.5 \pm 79 \mathrm{~km}$ feeding and watering were not practiced by most of traders $(65 \%)$ during the travels. This indicated the need to create awareness on feeding and watering particularly in long journey.

Most of the traders (75\%) transported cattle by mixing different ages, breeds and sex. This might be a causes for transportation stress and even death. This finding was supported by Bulitta et al. (2012) who reported that mal-management of animals during transportation increased in the prevalence of death and injuries. Cattle close to terminal market were trekked by foot and had the opportunity to get feed and drink water along the roadsides. As most cattle transport were conducted by vehicle used to transport goods like ISUZE and trakers it is important to create awareness on proper uses of vehicle designed like cargo for transporting animals. Introducing appropriate vehicle for cattle transport and proper density (space) for cattle need to be aware to traders. 
Table 8. Transport of cattle to terminal market

\begin{tabular}{|c|c|c|c|c|c|c|c|c|}
\hline \multirow{3}{*}{ Variable } & \multirow{3}{*}{ Attribute } & \multicolumn{4}{|c|}{ Location } & \multirow{2}{*}{\multicolumn{2}{|c|}{ Total n (40) }} & \multirow{3}{*}{$\chi^{2}$} \\
\hline & & \multicolumn{2}{|c|}{ Adama (20) } & \multicolumn{2}{|c|}{ Dire Dawa(20) } & & & \\
\hline & & $\mathrm{N}$ & $\%$ & $\mathrm{~N}$ & $\%$ & $\mathrm{n}$ & $\%$ & \\
\hline \multirow[t]{3}{*}{ Ways of transported } & By foot & 5 & 25 & 1 & 5 & 6 & 15 & \\
\hline & Vehicle & 14 & 70 & 17 & 85 & 31 & 77.5 & 3.29 \\
\hline & Both & 1 & 5 & 2 & 10 & 3 & 7.5 & \\
\hline \multirow[t]{3}{*}{ Ways of grouping } & Sex & 6 & 30 & 3 & 15 & 9 & 22.5 & 2.13 \\
\hline & Breed & 0 & 0 & 1 & 5 & 1 & 2.5 & \\
\hline & Mixed & 14 & 70 & 16 & 80 & 30 & 75 & \\
\hline \multirow[t]{2}{*}{ Watering and feeding } & Yes & 10 & 50 & 4 & 20 & 14 & 35 & \\
\hline & No & 10 & 50 & 16 & 80 & 26 & 65 & $3.95 *$ \\
\hline \multirow[t]{2}{*}{ Length of transport } & Min & $\mathrm{Ma}$ & Mean \pm SD & $\mathrm{Mi}$ & Mean & SD & Av. & \\
\hline & 50 & 350 & $156 \pm 96.3$ & 150 & $81 \pm 2$ & & $118.5 \pm 19$ & $25.78 *$ \\
\hline
\end{tabular}

$\mathrm{N}=$ Number of the respondents, Mixed = age, breed, breed, and location. $*(\mathrm{P}<0.05), \mathrm{SD}=$ standard deviation,

$\mathrm{Ma}=$ Maximum, $\mathrm{Mi}=$ Minimum, $\chi^{2}=$ Chi- square

\section{Perception of the trader on the beef quality determinant}

Traders' perception on beef quality determinant in the study areas are presented in Table 9. The result of the study indicated that all the respondents perceived that there were a numbers of factors, which affect quality of beef. The highest mean score on beef quality determinant by traders were beating cattle, availability of feed resource and agroecology of cattle managed. Eventhough determinant factors ranked different, all respondents agree for all factors listed in Table 9 contributed for determine beef quality.

Pre-slaughter animal handling condition like beating (during at production area, transport, market, lairage) mixing (different species, age, breeds), stock density, fighting, feed and water scarce were not only affect the welfare of the animal, but also has greater impacts on the quality on the meat produced from different species (Muchenje et al., 2009; Hemsworth et al., 211 and Cetin et al., 2012). In this study feeding watering during transport to market and speed of lories ranked as lowest impacts of meat quality determinant. Table 9.Traders' perception on beef quality determinant (Mean score)

\begin{tabular}{lcccc}
\hline Variable & Mean & SD & Rank & Decision \\
\hline Beating of cattle & 4.48 & 0.55 & 1 & Agree \\
Availability of feed resource & 4.43 & 0.5 & 2 & Agree \\
Agroecology of cattle & 4.35 & 0.53 & 3 & Agree \\
Age categories of cattle & 4.23 & 0.67 & 4 & Agree \\
Breeds of cattle & 4.1 & 0.73 & 5 & Agree \\
Means of transport & 4.08 & 0.85 & 6 & Agree \\
Sex & 3.9 & 0.84 & 7 & Agree \\
Cutting parts & 3.78 & 0.62 & 8 & Agree \\
Cooking methods & 3.7 & 0.68 & 9 & Agree \\
Slaughter methods & 3.68 & 0.69 & 10 & Agree \\
Carcass transportation & 3.5 & 0.75 & 12 & Agree \\
Mixing during transportation & 3.43 & 0.93 & 11 & Agree \\
Give rest/feed/water during transport & 3.3 & 1.02 & 13 & Agree \\
Speed of lories at transport & 3.25 & 0.99 & 14 & Agree \\
\hline
\end{tabular}

Mixing $=$ different age, sex, breed and location, $\mathrm{n}=$ Number of respondents, $\mathrm{SD}=\mathrm{Standard}$ deviation

\section{Preference traders for sex and ages of beef cattle}

Traders preference for sex and age of cattle used for beef purpose study areas are presented in Table 11. In the current study, traders preferred male beef cattle aged between 4 to 6 and 6 to 9 years as $1^{\text {st }}$, and $2^{\text {nd }}$, respectively, while female cattle between 6 to 9 and 4 to 6 years were preferred, respectively. Beef cattle less than four years were relatively less demanded both sexes for beef purpose. This result was reported by respondent as the lack of well-developed muscle by young cattle under existing production system. However, as the international meat quality point of views greater 4 years beef cattle were as though meat source. Because as age of animal increases meat tenderness was decreased. 
Table 11 Traders preference for ages and sex of cattle used for beef purpose

\begin{tabular}{|c|c|c|c|c|c|c|c|c|}
\hline \multirow{2}{*}{ Age (yr) } & \multicolumn{6}{|c|}{ Male beef cattle ranking value $(n=39)$} & \multirow{2}{*}{ Mean score } & \multirow{2}{*}{ Rank } \\
\hline & $1^{\text {st }}$ & $2^{\text {nd }}$ & $3^{\text {rd }}$ & $4^{\text {th }}$ & $5^{\text {th }}$ & $6^{\text {th }}$ & & \\
\hline $4-6$ & 24 & 9 & 5 & 2 & 0 & 0 & 69.43 & 1 \\
\hline $6-9$ & 4 & 23 & 4 & 0 & 0 & 0 & 66.65 & 2 \\
\hline $9-12$ & 2 & 5 & 20 & 10 & 3 & 0 & 53 & 3 \\
\hline $2-3$ & 1 & 2 & 10 & 20 & 3 & 0 & 48.05 & 4 \\
\hline$<2$ & 0 & 0 & 0 & 3 & 18 & 19 & 31.03 & 5 \\
\hline$>12$ & 0 & 1 & 1 & 6 & 13 & 16 & 31.05 & 6 \\
\hline \multirow{2}{*}{ Age (yr) } & \multicolumn{6}{|c|}{ Female beef cattle Ranking value $(n=25)$} & \multirow{2}{*}{ Mean score } & \multirow{2}{*}{ Rank } \\
\hline & $1^{\text {st }}$ & $2^{\text {nd }}$ & $3^{\text {rd }}$ & $4^{\text {th }}$ & $5^{\text {th }}$ & $6^{\text {th }}$ & & \\
\hline $6-9$ & 15 & 7 & 6 & 9 & 0 & 0 & 68.65 & 1 \\
\hline $4-6$ & 9 & 15 & 7 & 3 & 0 & 0 & 64.03 & 2 \\
\hline $2-3$ & 5 & 5 & 8 & 9 & 6 & 1 & 52.68 & 3 \\
\hline $9-12$ & 2 & 2 & 11 & 10 & 9 & 0 & 49.03 & 4 \\
\hline$>12$ & 0 & 2 & 1 & 3 & 16 & 12 & 34.88 & 5 \\
\hline$<2$ & 2 & 3 & 1 & 3 & 2 & 23 & 33.47 & 6 \\
\hline
\end{tabular}

\section{Preference of traders for cattle breeds}

Traders preference for breeds of cattle for beef purpose the study area is presented in Table 12. More than seven breeds were accessed in the market. These breeds have demanded differently based on availability on market. Traders ranked demand of availability breeds on market accordingly Harar, Arsi, Bale, Boran, Karayu, Ogaden (Isa) and crossbreed, respectively.

In general, Harar breed had high demand by butchers than other breeds because of higher tender meat and marbling, according to respondents. They suggested that tender beef from Harar breed used for preparation of special meal, especially for raw meat eater locally called "Kurt". The better tenderness of the breed might be based on feeding system used in Hararghe fattening practice i.e sorghum and maize forage. Sorghum forage has high starch content, which can activities fermentation for the rumen microbial degradation (Ulises et al., 2018). Activating rumen microorganism has an advantage to increase feed intake by animal, which result in good body conformation. The genetic contribution for tenderness of Harar breed (sanga) needs further investigation. Similarly, Belete et al. (2010) reported that fattened beef cattle from Harar market had premium price up to $50 \%$ over the other cattle breed in the Addis Ababa market.

Despite the demand for the breed, traders in Adama terminal market stated that they could not get sustainable supply of Harar breed to market throughout the year. The lack of sustainability might be the production system, which was market not market-oriented. As Dire Dawa was, center for this cattle breed, the market was sustainably supplied with the breed. The Arsi cattle breed was the second preferred breed for beef purpose at Adama terminal market. The demands of Arsi breed was higher by butchers in study area. Traders responded that Borana bulls ages four to six years needed in-feedlot as for export market than local markets. This was due to the good performance of breed on fattening and highly demanded by export market. The current finding is supported by Genet et al. (2017) who reported that Boran breed cattle were the most preferred breed for fattening purpose than the other breed types in commercial beef cattle fattening center.

Table 12.Traders preference for breeds of cattle used for beef purpose

\begin{tabular}{lllllllllll}
\hline Breed & 1 & 2 & 3 & 4 & 5 & 6 & 7 & $\mathrm{~N}$ & Mean score & Rank \\
\hline Harar & 23 & 5 & 10 & 2 & 0 & 0 & 0 & 40 & 69.85 & 1 \\
Arsi & 14 & 10 & 5 & 4 & 2 & 0 & 1 & 36 & 65.14 & 2 \\
Bale & 1 & 12 & 4 & 7 & 6 & 7 & 2 & 36 & 55.42 & 3 \\
Boran & 2 & 7 & 8 & 12 & 6 & 1 & 0 & 36 & 54.64 & 4 \\
Karayu & 0 & 0 & 3 & 4 & 20 & 4 & 5 & 36 & 41.14 & 5 \\
Ogaden & 0 & 1 & 2 & 4 & 1 & 16 & 12 & 36 & 34.64 & 6 \\
Cross & 0 & 0 & 4 & 3 & 1 & 11 & 17 & 36 & 32.78 & 7 \\
\hline
\end{tabular}

$\mathrm{n}=$ Number of respondent

\section{CONCULUSION AND RECCOMANDATION}

Ethiopia has large numbers of livestock resource. However, the contribution of livestock and livestock products potential is underutilized. This study was conducted with the objective of evaluating eating quality of beef produced in wet and dry season at public abattoirs in Adama, Dire Dawa and Haramaya University. Survey data was collected from 90 respondents of beef cattle producers and traders. The data were analyzed by using SPSS version (20). The perception of stakeholders was analyzed through a Likert scale and Garret ranking methods. 
Most of the producers were kept cattle for the multiple purposes, except intensive farm around Adama and Dire Dawa that were mostly for a single purpose. Crop residues and natural pasture were the most economically important animal feed resource through-out the year. Depending on the type of crop production, the availability of crop residues was the most access in study areas. Producers kept old cattle greater than 5 years of age. They sold animals for satisfy emergency cash need, purchase agriculture input and fee for children school sale of cattle were, commonly without proper market information. Feed shortage, animal health, lack of stock, lack technology and fattening place were the major constraints of beef cattle production in the study area.

Traders collect cattle from Adama terminal market, which came from Arsi, Bale, and West Hararghe zonal district. Cattle for Dire Dawa terminal market came from East and of West Hararghe zonal districts. The price of beef cattle was determined by bargaining between buyers and sellers. Most of the traders transported cattle to their destination by traveling an average of $118.5 \pm 19 \mathrm{~km}$ via vehicle animal were mixed irrespective of their ages, breeds, and sex during transport. Traders perceived that beating, scarcely of feed resource and source agroecology were the major factor that influenced beef qualities. Major beef cattle access for Adama and Dire Dawa terminal markets were Harar, Arsi, Bale, Boran, Karayu, Ogade

In general, Harar breed had highly demanded than other breeds local markets. Whereas Boran breeds were demanded for the exporter purpose. Even though the Harar breed had higher demands there was no sustainable supplies to Adama terminal market. However, Dire Dawa terminal market and Harmaya University traders have been sustainably supplied with Harar breed. Based on the conclusion made, it is possible to suggest the following recommendations to improve the quality of beef in Ethiopia.

1. A strategy should be developed that encourage premium payment for young cattle that that were not served for draft purpose.

2. Creating awareness among cattle producers on quality beef from young bulls, on establishing improved forage and improving the nutritional quality of crop residues.

3. Develop breeding improvement design for Harar cattle breeds for continuous supply to markets.

4. Training should provide for producers on scientific ration formulation and feed the animals based on body weight of the animals to hasten finishing time and decrease the problem of feed scarce problem

5. Develop a strategy to introduce weigh-based cattle pricing policy even if at terminal market.

\section{Conflict of interest}

The authors declared that there is no conflict of interest between authors and organizations.

\section{ACKNOWLEDGMENT}

The authors would like to express the deep gratitude to Oromia Agricultural Research Institute and Kansas State University for funding this research Work. The authors also like to thank Mechara Agricultural research Center staff Sudi D, Tamrat D and Bayisa M, from Dilla University Olyad M. and Bayisa B., from Arsi University Delengi M., from Sinana Research Center Falmata G ., from Fadis Research Center Worku B., from Haramaya University Gemachu T, Lenjisa D and Galata G. for their friendly assistance during data collection for this study. Lastly but not least, the authors wish to thanks to all finance personal at Mechara Agricultural Research center (McARC) and Oda Bultum University (OBU) for facilitating research logistics.

\section{REFERENCES}

Adugna Tolera. 2008. Feed Resources and Feeding Management: Ethiopia Sanitary \& Phytosanitary Standards and Livestock \& Meat Marketing Program (SPS-LMM) Texas Agricultural Experiment Station (TAES)/Texas A\&M University: A manual for feedlot operators and development workers, Addis Ababa.

Arse Gebeyehu, Mohammed Yousuf, Ameha Sebsibe. 2013. Evaluation of Eating Qualities of Ethiopian Beef of Arsi Cattle in Adama Town, Oromia, Ethiopia. International Journal of Agriculture Innovations and Research, 1(6): 2319-1473.

Belay Duguma, Azage Tegegne and Hegde, B.P. 2012. Smallholder Livestock Production System in Dandi District, Oromia Regional State, Central Ethiopia. Global Veterinaria, 8 (5): 472-479.

Belete Anteneh, Azage Tagegn, Fekadu Beyene and Berhanu Gabrahadin. 2010. Cattle milk and meat production and marketing system and opportunities for market orientation in Fogera woreda, Amhara region, Ethiopia. IPMS (Improving Productivity and Market Success) of Ethiopian farmers project working papers 19. Nairobi, Kenia: ILRI

Bülent Ergönül, 2017. Influence of Different Cooking Methods on Quality Attributes of Chicken Breast Meat. Celal Bayar University Journal of Science, 13 (4): 883-885.

CSA (Central Statistical Agency). 2016/17. Agricultural Sample Survey. Livestock, Poultry and Beehives population (private peasant holdings). Federal Democratic Republic of Ethiopia Central Statistical Authority, Addis Ababa, Ethiopia.

Diriba Geleti. 2014. Agronomic and Nutritional Evaluation of Selected Forage Legumes and Locally Available 
Feedstuff, and Characterization of Forage and Dairy Innovation Systems in Bako and Nekemte Peri-Urban Areas, Oromia, Ethiopia. PhD. Dissertation Addis Ababa University, College of Veterinary Medicine and Agriculture, Bishoftu.

EMDIDI (Ethiopian Meat and Dairy Industry Development Institute ). 2016. Ethiopian Agro-Industry Strategy Meat Industry Sub-Sector Strategic Plan (2015-2025). Addis Ababa-Ethiopia.

Eyob Eshetu and Zewudu Abraham. 2016. Review on live animal and meat export marketing system in Ethiopia: challenges and opportunities. Scientific and innovative Research Journal, 5(2): 59-64.

Genet Dadi, Urge M, Teklebrhan T. 2017. Assessment of Commercial Beef Cattle Fattening Practices and performance in East Shoa Zone. Int J Agric Sc Food Technol, 3(3): 067-076. DOI: http://doi.org/10.17352/2455-815X.000025

Harko Halala. 2015._Review of Beef Cattle Value Chain in Ethiopia. Journal of Industrial Engineering Letters, 5 (7): 2225-0581.

Henry, E. Garrett. 1969. Statistics in psychology and Education sixth edition. Bombay 400038 , India.

Josefine Jerlström. 2013. Animal welfare in Ethiopia: transport to and handling of cattle at markets in Addis Ababa and Ambo._Swedish University of agricultural sciences,_department of animal nutrition and management, 461.

Kefyalew Alemayehu. 2011. Value chain assessment of beef cattle production and marketing in Ethiopia: challenges and opportunities of linking smallholder farmers to the markets. Livestock research for rural development. Volume 23. Article \#255.

Likert, R.1932. A technique for the measurement of attitudes. Archives of Psychology, 22(140):1-55.

Matawork Milkias. 2017. Beef Cattle Production Systems, Marketing and Constraints in Ethiopia. Journal of Marketing and Consumer Research, Vol.32: 2422-8451.

Solomon Bogale, Solomon Melaku and Alemu Yami. 2008. Matching livestock systems with available feed resources in the Bale Highlands of Ethiopia._Outlook on Agriculture, 37 (2):105-110.

Bulitta Sori Fufa, Girma Gebresenbet, Teshoma Bosona. 2012. Animal Handling during Supply for Marketing and Operations at an Abattoir in Developing Country: The case of Gudar market and Ambo Abattoir, Ethiopia. Journal of Service Science and Management, 5: 59-68.

Tadesse Estefanos, Tesfaye Alemu, Feyisa Hundesa, Gashaye Weldu, Tatek Weldu, Tesfaye Balay and Osho Tibesso. 2014. Cattle production in the highlands of Hararge: Case study for East and West Zones of the high lands of Harerge, Eastern Ethiopia. Basic Research Journal of Agricultural Science, 3 (12):122-130.

Tasfaye Moroda. 2016. Assessment of beef cattle production, management practices and marketing system in Lume district East Shoa, Ethiopia. MSc Thesis Hawasa University.

Ulises Alejandro, González Garcíaa, Luis Corona, Francisco Castrejon-Pinedac, Joaquim Balcells, Octavio Castelan Ortegaa and Manuel Gonzalez-Ronquillo, 2018. A comparison of processed sorghum grain using different digestion techniques. Journal of Applied Animal Research, 46 (1): 1-9.

Yesihak Yusuf and Edward Cotington Webb. 2014. Ethiopian beef carcass characteristics. Africa Journal of Agriculture, 9(51): 3766- 3775.

Yidnekachew Alemayehu, Asmera Adicha, Mesfin Mengistu and Binyam Eshetu. 2016. Assessments of market Oriented beef cattle fattening System under farmer management condition in South Omo zone of SNNPR. Current Research in Agricultural Sciences, 3 (2): 21-45. 
Appendix 1. Garret ranking convert table

\begin{tabular}{|c|c|c|c|c|c|c|c|c|c|}
\hline percent & score & percent 2 & score3 & percent 3 & score4 & percent 4 & score5 & percent 5 & score6 \\
\hline 0.09 & 99 & 8.33 & 77 & 40.01 & 55 & 83.31 & 31 & 81.99 & 32 \\
\hline 0.20 & 98 & 9.17 & 76 & 41.97 & 54 & 84.56 & 30 & 98.32 & 10 \\
\hline 0.32 & 97 & 10.06 & 75 & 43.97 & 53 & 85.75 & 29 & 98.58 & 9 \\
\hline 0.45 & 96 & 11.03 & 74 & 45.97 & 52 & 86.89 & 28 & 98.82 & 8 \\
\hline 0.61 & 95 & 12.04 & 73 & 47.98 & 51 & 87.96 & 27 & 99.03 & 7 \\
\hline 0.78 & 94 & 13.11 & 72 & 50.00 & 50 & 88.97 & 26 & 99.22 & 6 \\
\hline 0.97 & 93 & 14.25 & 71 & 52.02 & 49 & 89.94 & 25 & 99.39 & 5 \\
\hline 1.18 & 92 & 15.44 & 70 & 54.03 & 48 & 90.83 & 24 & 99.55 & 4 \\
\hline 1.42 & 91 & 16.69 & 69 & 56.03 & 47 & 91.67 & 23 & 99.68 & 3 \\
\hline 1.68 & 90 & 18.01 & 68 & 58.03 & 46 & 92.45 & 22 & 99.80 & 2 \\
\hline 1.96 & 89 & 19.39 & 67 & 59.99 & 45 & 93.19 & 21 & 99.91 & 1 \\
\hline 2.28 & 88 & 20.93 & 66 & 61.94 & 44 & 93.86 & 20 & 100.00 & 0 \\
\hline 2.69 & 87 & 22.32 & 65 & 63.85 & 43 & 94.49 & 19 & & \\
\hline 3.01 & 86 & 23.88 & 64 & 65.75 & 42 & 95.08 & 18 & & \\
\hline 3.43 & 85 & 25.48 & 63 & 67.48 & 41 & 95.62 & 17 & & \\
\hline 3.89 & 84 & 27.15 & 62 & 69.39 & 40 & 96.11 & 16 & & \\
\hline 4.38 & 83 & 28.86 & 61 & 71.14 & 39 & 96.57 & 15 & & \\
\hline 4.92 & 82 & 30.61 & 60 & 72.85 & 38 & 96.99 & 14 & & \\
\hline 5.51 & 81 & 32.42 & 59 & 74.52 & 37 & 97.37 & 13 & & \\
\hline 6.14 & 80 & 34.25 & 58 & 76.12 & 36 & 97.72 & 12 & & \\
\hline 6.81 & 79 & 36.15 & 57 & 77.68 & 35 & 98.04 & 11 & & \\
\hline 7.55 & 78 & 38.06 & 56 & 79.17 & 34 & 80.61 & 33 & & \\
\hline 5047 & & & & & & \\
\end{tabular}

Source: Garret, 1969 